\title{
The Known and the Unknown Herbert ${ }^{1}$
}

Poetry and literature more generally, especially truly great literature, give rise to an infinite number of possible interpretations, discussions, and contexts. It seems inexhaustible in creating meanings constantly interpreted anew by subsequent generations of professional researchers and ordinary readers. Twenty years have passed since the death of Zbigniew Herbert, and the number of publications devoted to his life and work continues to multiply. We will make our small contribution as well. One can ask if these reflections add a new quality to the reception of the work of "Mr. Cogito." However, even a cursory overview of the titles of published books and the themes raised on this occasion proves that there still is unexplored terrain in Herbert studies, and it seems that even grounded diagnoses are at times disputed and verified. Research and methodological perspectives are changing. In recent years, there has been a growth in interest in the poet's life and his creative technique, to which the texts contained in this issue also attest. A topic that is frequently discussed is the attitude of Herbert himself to the transcendent and his position towards it as articulated in his work. Metaphysical motifs as well as questions about the presence of God and the shape of the afterlife are especially clear in the poet's last volumes; they also became a frequent topic of analysis and debate shortly after his death. ${ }^{2}$ The volatility and diversity of such reflections appears to be a desirable phenomenon; the movement of thought corresponds to the values preached by Herbert, who perversely diagnosed:

1 Originally published in Konteksty Kultury 2018, vol. 15, no. 1 (the Polish title: "Herbert znany i nieznany - uwagi wstępne”).

2 For example, we can reference here Paweł Lisicki’s sketch, "Puste niebo Pana Cogito" [in:] idem, Nie-ludzki Bóg, Warszawa 1995 (published during the poet's lifetime); the collected volume Między nami a świattem. Bóg i świat w twórczości Zbigniewa Herberta, ed. G. Halkiewicz-Sojak, J.M. Ruszar, R. Sioma, Toruń-Kraków 2012; or the book Mirosław Dzień, Motywy eschatologiczne w poezji Zbigniewa Herberta. Studium analityczno-interpretacyjne, vol. 1-2, Bielsko-Biała 2014. 
the common idiom

overestimates thoughts' nobility

a majority of them

stand motionless (...)

they circle around

(...)

under the low

overcast

firmament

of the skull. ${ }^{3}$

In his article "Herbert: A Short History of Reading," Wojciech Ligęza discusses the reception of the poet's oeuvre over the course of more than sixty years, concentrating mostly on publications that have appeared since Herbert's death, in a synthetic presentation. Ligęza situates his broad topic of study around the motifs of the transformations of the image of the artist and the determinants of this portrait; the changing ways of reading; and the multiplicity of interpretive frames of individual poems. He discusses four books in detail: Mateusz Antoniuk's Otwieranie gtosu. Studium o wczesnej twórczości Zbigniewa Herberta (do 1957 roku); Jolanta Dudek's Granice wyobraźni Granice stowa. Studia z literatury porównawczej XX wieku; Karol Hryniewicz's Cogito i dubito. Dyskurs estetyczny w poezji Zbigniewa Herberta i Tadeusza Różewicza; and Agnieszka Kramkowska-Dąbrowska's Gabinet luster. Śmiech w twórczości Zbigniewa Herberta. Undertaking the exceptionally difficult task of following the reception of this work, the author of the article does not only provide us a very useful study, but he also points to an essential trait of Herbert studies: the creative motion that broadens knowledge about the poet's work and gives rise to reflections transcending the subject of study.

Ireneusz Ziemiński focuses on one of the aspects of metaphysics in Herbert's work. In the article "In-Human Immortality: Several Philosophical Comments on the Idea of Eternity in Zbigniew Herbert's Poetry" he attempts to reconstruct the images of the afterlife, God, and the perspective of the deceased person that emerge from poems contained in volumes from different periods, taking into account the philosophical perspective. The article presents problems related to both the vision of heavenly (transcendental) eternity understood as a new form of human existence after death, as well as the concept of earthly (immanent) eternity consisting of immortal fame or the human experience of transcending time and the acute sense of its passage. The author pays especial attention to poetry in which the character Mr. Cogito appears in order to eventually point

3 Z. Herbert, "Mr. Cogito and the Movement of Thought" [in:] idem, The Collected Poems: 1956-1998, trans. A. Valles, London 2007, p. 287. 
towards the tragedy of this figure in the context of possible choices concerning the vision of immortality.

Articles by Francesca Fornari and Mateusz Antoniuk exemplify research accompanied by an analysis of the contents of archives. The Venetian researcher focuses on the poem "Mr. Cogito and the Imagination" and the notes in the draft copy. Comparisons allow us to note abandoned ideas (for example, the motif of Daedalus and the reference to the Upanishads), but also to witness the process of constructing a conception of identity or crystallization of the meaning of tautology that is essential to interpreting the work. The author devotes a lot of attention to this concept, analyzing it within the context of two others: metamorphoses and truth. The reflection concerning the poem under discussion makes it possible to make reference to the topic of realism and Herbert's attitude towards reality.

Mateusz Antoniuk studies a text from poet's archive in which the mythological figure of Narcissus appears. The author's conclusion is that Herbert dealt with the reinterpretation of the myth for more than a dozen years, creating three variants of this figure: Narcissus the philosopher desiring self-knowledge, Narcissus tragically rebelling against his own fate, and Narcissus the philosopher of auto-reduction. Antoniuk makes the poem "Wisła" ("Vistula"), on which Herbert worked in 1953, an interesting context for these reflections. There, the narcissistic myth is the source of the metaphor in the context of the discourse on the nation's history, present, and past, which differs greatly from later conceptions related to the figure of Narcissus. At the same time, the author of the piece points towards the persistent return of this topic in the poet's reflections.

In this issue, articles related to the work of the author of "Mr. Cogito" are accompanied by reviews of two recently published books that confirm the notion that interest in the author's life and text-forming process are on the rise. Joanna Zach write about Andrzej Franaszek's biography of Zbigniew Herbert. Much has already been said about the poet and it would seem that his work is well known, but the process of discovery continues. The movement of thought persists, and we can see that it does not move in circles, but instead leads to new insights.

Dorota Siwor Editor-in-Chief of this issue 